\title{
KEBIJAKAN HUKUM PIDANA DALAM PERLINDUNGAN HAK KEBEBASAN BERSERIKAT BAGI PEKERJA/BURUH INDONESIA
}

\author{
Aris Septiono, ${ }^{1}$ Nyoman Serikat Putra Jaya ${ }^{2}$
}

\begin{abstract}
Abstrak
Penelitian ini bertujuan untuk mengetahui kebijakan hukum pidana dalam melindungi hak kebebasan berserikat bagi pekerja atau buruh di Indonesia. Metode Penelitian ini menggunakan pendekatan yuridis normative. Penelitian ini juga akan menggunakan data komparatif undang-undang di Negara lain yang mengatur mengenai perlindungan hak kebebasan berserikat, sedangkan data Dianalisis secara kualitatif-normatif. Hasil penelitian ditemukan bahwa; Pertama,Kebijakan hukum pidana dalam perlindungan hak kebebasan berserikat bagi pekerja/buruh Indonesia adalah dengan menggunakan Kitab Undang-Undang Hukum Pidana (KUHP), Undang-Undang Nomor 21 Tahun 2000 tentang Serikat Pekerja/serikat Buruh, Undang-Undang Nomor 13 Tahun 2003 tentang Ketenagakerjaan, Undang-Undang Nomor 9 Tahun 1998 tentang Kemerdekaan Menyampaikan Pendapat di Muka Umum. Kedua,Kebijakan aplikasi hukum pidana saat ini dalam perlindungan hak kebebasan berserikat bagi pekerja/buruh Indonesia dalam kaitan dengan Hak Asasi Manusia untuk penyidikan dalam penegakan hukum selain kepolisian juga diberikan wewenang kepada Pejabat Pegawai Negeri Sipil (PPNS) yang bertugas pada instansi yang bertanggungjawab di bidang ketenagakerjaan. Ketiga,Kebijakan formulasi hukum pidana dalam perlindungan hak kebebasan berserikat bagi pekerja/buruh Indonesia dalam kaitan dengan Hak Asasi Manusia yang akan datang, hanya terdapat pada konsep KUHP 2012 .
\end{abstract}

Kata Kunci: Pidana, Kebebasan Berserikat, Buruh/Pekerja.

\footnotetext{
${ }^{1}$ Mahasiswa Program Studi Magister IImu Hukum UNDIP

${ }^{2}$ Dosen Program Studi Magister Ilmu Hukum UNDIP
} 


\section{A. Pendahuluan}

$\begin{array}{rrr}\text { Hak } & \text { atas } & \text { kebebasan } \\ \text { berserikat } & \text { bagi } & \text { pekerja }\end{array}$ diimplementasikan dalam bentuk serikat pekerja yang berfungsi sebagai wadah penampung dan penyalur aspirasi pekerja dalam hubungan industrial. Pengimplementasian hak atas kebebasan berserikat dalam bentuk serikat pekerja mengandung nilai yang sangat strategis bagi pekerja, sebab dengan pengimplementasian tersebut membuat hak atas kebebasan berserikat bukan hanya berfungsi sebagai hak fundamental tapi juga berfungsi sebagai hak instrumental. Pengertian hak instrumental yang dimaksud di sini adalah bahwa dengan perwujudan hak atas kebebasan berserikat dalam bentuk serikat pekerja, mengandung konsekuensi bahwa pekerja dapat menggunakan hak tersebut, untuk memperoleh hak-hak lain yang seharusnya diterima oleh pekerja. Dengan kata lain hak atas kebebasan berserikat dijadikan sebagai instrumen untuk menuntut kenaikan upah, ikut berperan dalam membentuk perjanjian kerja bersama, menolak dilakukannya pemutusan hubungan kerja, berunding bersama dan mengajukan tuntutan untuk

Dalam era reformasi saat ini, setelah diundangkannya UndangUndang Nomor 21 Tahun 2000, pekerja/buruh diberikan kebebasan untuk membentuk atau mendirikan serikat pekerja/serikat buruh. Kesempatan ini digunakan sepenuhnya oleh para pekerja/buruh untuk membentuk dan mendirikan serikat pekerja/serikat buruh, berdasarkan hasil verifikasi yang dilakukan oleh Kementrian Tenaga Kerja dan Transmigrasi pada tahun
2008, tercatat ada 3 Konfederasi Serikat Pekerja/Serikat Buruh, 71 Federasi Serikat Pekerja/Serikat Buruh dengan jumlah anggota 3.405.635 pekerja. ${ }^{3}$ Banyaknya serikat pekerja yang berdiri di Indonesia, di satu sisi merupakan bukti berjalannya sebagian hak kebebasan berserikat tetapi belum dalam arti sepenuhnya. Perlu dilihat juga sejauh mana hak-hak sebagai sebuah serikat pekerja dapat terpenuhi, adakah kesempatan bagi pengurus serikat pekerja untuk menjalankan kegiatan organisasi dalam kerja, apakah serikat pekerja dilibatkan dalam kebijakan pengupahan di perusahaan, seberapa besar "bargaining position" serikat pekerja dalam melakukan dialog dan perundingan dengan pengusaha maupun pemerintah, dan masih banyak lagi.

Kasus-kasus pelanggaran kebebasan berserikat di perusahaan sebenarnya banyak terjadi, akan tetapi sedikit sekali yang dilaporkan secara pidana, sehingga yang muncul adalah perselisihan hubungan industrial. Berikut beberapa contoh kasus pelanggaran kebebasan berserikat yang berhasil dihimpun: ${ }^{4}$

a) Perkara Bambang Wisudo, wartawan harian Kompas yang dipecat karena dianggap melakukan tindakan indisipliner lantaran tidak bersedia dimutasi ke Ambon. Bambang adalah Sekretaris Perkumpulan Karyawan Kompas yang sempat mempertanyakan kepemilikan

\footnotetext{
${ }^{3}$ Sumber data dari Direktur Pembangunan Hubungan Industrial, Kementerian Tenaga Kerja dan Transmigrasi Republik Indonesia, tanggal 15 Mei 2008

${ }^{4}$ Trade Union Right Centre, "Kebebasan Berserikat Jalan di Tempat", Jakarta: 1 September 2008
} 
saham kolektif karyawan sebesar 20 persen. $^{5}$

b) Kasus pemutusan hubungan kerja terhadap Mirisnu Viddiana.Ia adalah Ketua Serikat Pegawai Bank Mandiri. Ia dipecat karena dianggap bertanggung jawab atas aksi unjuk rasa ribuan pegawai bank pelat merah di hari libur. Pengadilan Hubungan Industrial Jakarta melegalkan pemutusan hubungan kerja ini. ${ }^{6}$

c) Kasus Pemutusan Hubungan Kerja 4 orang pekerja yang juga pengurus Pimpinan Unit Kerja Federasi Serikat Pekerja Metal Indonesia di PT. King Jim Indonesia, Pasuruan Jawa Timur. Kasus ini bermula pihak pengusaha yang tidak mau menanggapi permintaan serikat pekerja untuk berunding membuat Perjanjian Kerja Bersama.

d) Di semarang, 6 orang pengurus serikat pekerja di PT. AST Indonesia yang di Pemutusan Hubungan Kerja karena bergabung dengan Federasi Serikat Pekerja Metal Indonesia, dengan alasan melakukan kesalahan berat melanggar Perjanjian Kerja Bersama. ${ }^{8}$

Dan masih banyak lagi kasuskasus pelanggaran kebebasan berserikat yang terjadi dan tidak terungkap. Komite Kebebasan Berserikat Organisasi Buruh Internasional (ILO) Geneva mencatat, jumlah kasus pelanggaran

\footnotetext{
${ }^{5} \mathrm{http}: / / \mathrm{www} \cdot \mathrm{hukumonline.com/}$, diakses 5 Juli 2012

${ }^{6}$ http://siaranpers.blogspot.com/, diakses 5 Juli 2012

${ }^{7}$ http://hukumonline.com/, diakses 5 Juli 2012

${ }^{8}$ http://www.suaramerdeka.com/, diakses 5 Juli 2012
}

kebebasan berserikat di Indonesia yang telah dilaporkan ke International Labor Organization hingga tahun 2007 mencapai enam kasus. Sedangkan kantor International Labor Organisation Jakarta mendapat tembusan surat laporan atau pengaduan pelanggaran kebebasan berserikat, di tahun 2008 sekitar 58 kasus. ${ }^{9}$

Berdasarkan kenyataan tersebut diatas dalam rangka penanggulangan masalah penghalang-halangan kebebasan berserikat (anti union) maka diperlukan suatu pendekatan yang berorientasi kebijakan hukum pidana. Kebijakan penanggulangan dengan hukum pidana adalah merupakan usaha yang rasional dalam rangka menanggulangi kejahatan. Sebagai kebijakan yang rasional maka kebijakan tersebut harus berhubungan dengan kebijakan aplikatif yaitu kebijakan untuk bagaimana mengoperasionalisasikan Peraturan Perundang-undangan hukum pidana yang berlaku pada saat ini dalam rangka melindungi hak kebebasan berserikat bagi buruh Indonesia.

Berdasarkan uraian tersebut diatas, maka yang menjadi perumusan masalah dalam usulan penelitian ini adalah sebagai berikut: 1). Bagaimana kebijakan hukum pidana saat ini dalam memberikan perlindungan atas hak kebebasan berserikat bagi pekerja/buruh dalam kaitan dengan Hak Asasi Manusia; 2).Bagaimana kebijakan aplikasi hukum pidana saat ini dalam memberikan perlindungan atas hak kebebasan berserikat bagi

\footnotetext{
${ }^{9}$ wawancara dengan Soeharjono (National Project Coordinator ILO / ACTRAV Jakarta), di Jakarta, 15 Februari 2009
} 
pekerja/buruh dalam kaitan dengan Hak Asasi Manusia. 3). Bagaimana kebijakan hukum pidana dalam rangka perlindungan hak kebebasan berserikat bagi pekerja/buruh yang merupakan bagian dari hak asasi manusia di masa datang.

\section{Metodologi}

Penelitian ini menggunakan pendekatan yuridis normatif, yaitu dengan mengkaji atau menganalisis data sekunder yang berupa bahanbahan hukum sekunder dengan memahami hukum sebagai perangkat peraturan atau norma-norma positif di dalam sistem perundang-undangan yang mengatur mengenai kehidupan manusia. Jadi penelitian ini dipahami sebagai penelitian kepustakaan, yaitu penelitian terhadap data sekunder. ${ }^{10}$ Penelitian ini juga akan menggunakan data komparatif undang-undang di Negara lain yang mengatur mengenai perlindungan hak kebebasan berserikat.

Data Dianalisis secara kualitatif-normatif dengan jalan menafsirkan dan mengkonstruksikan pernyataan yang terdapat dalam dokumen dan perundang-undangan. Normatif karena penelitian ini bertitik tolak dari peraturanperaturan yang ada sebagai norma hukum positif, sedangkan kualitatif berarti analisis data yang bertitik tolak pada usaha penemuan asas-asas dan informasi baru.

\section{Kerangka Teori}

Penggunaan hukum pidana dalam mengatur masyarakat, melalui peraturan perundangundangan pidana, pada hakekatnya merupakan bagian dari suatu langkah kebijakan (policy). Selanjutnya

\footnotetext{
${ }^{10}$ Soerjono Soekanto \& Sri Mamudji, Penelitian Hukum Normatif, Suatu Tinjauan Singkat, Rajawali, Jakarta, 1985, hal. 15
}

untuk menentukan bagaimana suatu langkah yang rasional dalam melakukan kebijakan tidak dapat pula dipisahkan dari tujuan kebijakan pembangunan itu sendiri secara integral. Dengan demikian dalam usaha untuk menentukan suatu kebijakan apapun, termasuk kebijakan hukum pidana, selalu terkait dan tidak terlepaskan dari tujuan pembangunan nasional itu sendiri yaitu bagaimana mewujudkan kesejahteraan bagi masyarakat.

Kebijakan hukum pidana merupakan salah satu alternatif dari kebijakan criminal (criminal policy). Upaya melalui jalur penal merupakan upaya repressif yang dalam pelaksanaannya mengandung keterbatasan, sehingga perlu diimbangi dengan pendekatan non penal yang cenderung merupakan upaya preventif. Dengan demikian jika dilihat dari sudut politik kriminal secara makro dan global, maka upaya non penal menduduki posisi kunci dan strategis dari keseluruhan upaya politik kriminal. ${ }^{11}$ Hal ini tidaklah berarti bahwa upaya penal tidak penting, namun upaya penal merupakan sarana yang sangat vital dalam proses penegakan hukum (law enforcement) dalam menanggulangi kejahatan.Dengan demikian kebijakan hukum pidana berkaitan dengan proses penegakan hukum pidana secara menyeluruh, meliputi kebijakan hukum pidana material/substansial, hukum pidana formal (hukum acara pidana) dan hukum pelaksanaan pidana.

Hak Asasi Manusia (Human Rights) secara universal diartikan sebagai "those rights which are

\footnotetext{
${ }^{11}$ Barda Nawawi Arief, Bunga Rampai Kebijakan Hukum Pidana, Op. Cit, hal 49
} 
inherent in our nature and without which we cannot lives as human being" dapat didefinisikan sebagai hak-hak yang melekat (inherent) secara alamiah pada manusia dan tanpa hak-hak tersebut manusia tidak dapat hidup sebagai manusia. Hak asasi manusia adalah hak dasar yang dimiliki manusia sejak manusia itu dilahirkan. Hak asasi dapat dirumuskan sebagai hak yang melekat dengan kodrat kita sebagai manusia yang bila tidak ada hak tersebut, mustahil kita dapat hidup sebagai manusia. Hak ini dimiliki oleh manusia semata-mata karena ia manusia, bukan karena pemberian masyarakat atau pemberian negara. Maka hak asasi manusia itu tidak tergantung dari pengakuan manusia lain, masyarakat lain, atau Negara lain. Hak asasi diperoleh manusia dari Penciptanya, yaitu Tuhan Yang Maha Esa dan merupakan hak yang tidak dapat diabaikan.

berarti kebebasan fisik, yaitu kebebasan untuk bergerak dari satu tempat ke tempat yang lain. Ia mungkin pula berarti kebebasan psikologis yakni suatu ekspresi terbuka tentang sifat-sifat spontan dari watak manusia. Tapi mungkin juga kebebasan sipil, hak untuk bertindak dalam rangka peraturan Negara. "Bebas" berarti lepas sama sekali (tidak terhalang, terganggu dan lain sebagainya sehingga dapat bergerak, berbicara dan berbuat dengan leluasa). Membebaskan bermakna melepaskan dari ikatan, tuntutan, tekanan, hukuman, kekuasaan dan lain sebagainya. Sedangkan kebebasan adalah kemerdekaan atau dalam keadaan bebas. ${ }^{12}$ Menurut Loren Bagus,

${ }^{12}$ Kamus Besar Bahasa Indonesia, Jakarta, Balai Pustaka, 1990, hal 90 kebebasan (freedom) dipahami sebagai keadaan tidak dipaksa atau ditentukan oleh sesuatu dari luar, sejauh kebebasan disatukan dengan kemampuan internal definitive dari penentu diri. Bisa juga didefinisikan sebagai kemampuan dari seorang pelaku untuk berbuat atau tidak berbuat sesuai dengan kemampuan dan pilihannya. Mampu bertindak sesuai dengan apa yang disukai atau menjadi penyebab dari tindakantindakan sendiri. ${ }^{13}$

Hak untuk berkumpul, berorganisasi dan berserikat merupakan bagian dari Hak Asasi Manusia, yang secara umum diatur dalam:

1) Pasal 20 Universal Declaration of Human Rights (Deklarasi Universal Hak-Hak Asasi Manusia):

2) Pasal 22 Undang-Undang Nomor 12 Tahun 2005 tentang Pengesahan International Covenant on civil and Political Rights (Kovenan Internasional tentang Hak-hak Sipil dan Politik):

3) Pasal 8 Undang-Undang Nomor 11 Tahun 2005 tentang Pengesahan International Covenant on Economic, Social and Cultural Rights (Kovenan Internasional tentang HakhakSosial, Ekonomi dan Budaya):

4) Keputusan Presiden Republik Indonesia Nomor 83 Tahun 1998 tentang Pengesahan Convention (Number 87) Concerning Freedom of Association and Protection of The Right to Organise (Konvensi Nomor 87 tentang

\footnotetext{
${ }^{13}$ Loren Bagus, Kamus Filsafat, Jakarta: Gramedia Pustaka Utama, 2002, hal 406
} 
Kebebasan Berserikat dan Perlindungan Hak untuk Berorganisasi):

5) Undang-Undang Nomor 18 Tahun 1956 tentang Ratifikasi Konvensi No.98 Organisasi Perburuhan Interasional Mengenai Berlakunya Dasardasar dari Hak untuk Berorganisasi dan Berunding Bersama;

6) Pasal 28 dan pasal 28 E Undang - Undang Dasar 1945 dan perubahannya;

7) Pasal 24, pasal 25 dan pasal 39 Undang-Undang Nomor 39 Tahun 1999 tentang Hak Asasi Manusia;

8) Undang-Undang Nomor 21 Tahun 2000 tentang Serikat Pekerja/Serikat Buruh.

9) Pasal 104 Undang-Undang Nomor 13 Tahun 2003 tentang Ketenagakerjaan.

\section{Undang-Undang}

Nomor 21 Tahun 2000 tentang Serikat Pekerja/Serikat Buruh telah memberikan jaminan dan perlindungan hukum atas kebebasan berserikat bagi pekerja/buruh, tidak hanya sebatas pada hak pekerja/buruh secara individu untuk membentuk dan menjadi anggota serikat pekerja, tetapi juga hak serikat pekerja untuk menjalankan kegiatannya baik didalam perusahaan maupun diluar perusahaan. Dalam Pasal 1 ayat (3) Undang-Undang Nomor 21 Tahun 2000 tentang Serikat Pekerja/Serikat Buruh memberikan definisi yang jelas mengenai Serikat Pekerja/Serikat Buruh, yaitu:

Serikat pekerja/serikat buruh adalah organisasi yang dibentuk dan, oleh, dan untuk pekerja/buruh baik di perusahaan maupun di luar perusahaan, yang bersifat bebas, terbuka, mandiri, demokratis, dan bertanggung jawab guna memperjuangkan, membela serta melindungi hak dan kepentingan pekerja/buruh serta meningkatkan kesejahteraan pekerja/buruh dan keluarganya.

Pekerja/buruh yang akan membentuk Serikat pekerja/serikat buruh baik di dalam ataupun di luar perusahaan, harus memenuhi syarat dan mengikuti prosedur yang sudah ditetapkan oleh Undang-Undang Nomor 21 Tahun 2000 beserta peraturan pelaksanaannya. Setiap pekerja berhak untuk membentuk dan menjadi anggota serikat pekerja. Menurut Pasal 5 Undang-Undang Nomor 21 Tahun 2000 Syarat pembentukan serikat pekerja yakni memiliki jumlah anggota minimal 10 orang pekerja. Serikat pekerja yang sudah terbentuk, harus memberitahukan kepada Dinas Tenaga Kerja Kabupaten/kota sesuai dengan domisili serikat pekerja untuk kemudian dicatat, dengan dilampiri oleh daftar nama anggota pembentuk, Anggaran Dasar dan Anggaran Rumah Tangga serta susunan nama pengurus.

\section{B. Hasil Penelitian}

1. Kebijakan Formulasi Hukum Pidana di Indonesia Dalam Melindungi Hak Kebebasan Berserikat Bagi Pekerja/Buruh yang Berlaku Saat Ini;

Tindak pidana penghalanghalangan atau pemaksaan hak kebebasan berserikat tidak diatur secara jelas dalam KUHP. Namun perumusan tindak pidana kejahatan terhadap kemerdekaan orang dalam KUHP dapat digunakan untuk menjerat pelaku tindak pidana perampasan hak kebebasan berserikat. Tindak pidana kejahatan 
terhadap kemerdekaan orang diatur dalam Buku Kedua KUHP, Bab XVIII yaitu Pasal 335.

Dalam KUHP tidak memberikan pengertian dan batasanbatasan mengenai "memaksa" atau paksaan, kekerasan maupun perlakuan yang tak menyenangkan. Tidak diaturnya lebih lanjut mengenai hal tersebut maka untuk dapat menafsirkannya menggunakan interpretasi secara keilmuan yang dapat menggunakan berbagai literature seperti kamus, buku, keterangan pakar dan yurisprudensi. Dalam prakteknya, penerapan pasal 335 KUHP oleh Mahkamah Agung akan menekankan pada penafsiran terhadap "unsur paksaan" sebagai unsur utama yang harus ada dalam rangkaian perbuatan yang tidak menyenangkan. Unsur paksaan, menurut MA, tidak selalu diterjemahkan dalam bentuk paksan fisik, tapi dapat pula dalam bentuk paksaan psikis.

Didalam Bab VII tentang Perlindungan Hak Berorganisasi, Pasal 28 menyebutkan: Siapapun dilarang menghalang-halangi atau memaksa pekerja/buruh untuk membentuk atau tidak membentuk, menjadi pengurus atau tidak menjadi pengurus, menjadi anggota atau tidak menjadi anggota dan/atau menjalankan atau tidak menjalankan kegiatan serikat pekerja/serikat buruh dengan cara:

- melakukan pemutusan hubungan kerja, memberhentikan sementara, menurunkan jabatan, atau melakukan mutasi;

- tidak membayar atau mengurangi upah pekerja/buruh;

- melakukan intimidasi dalam bentuk apapun;
- melakukan kampanye anti pembentukan serikat pekerjal serikat buruh.
Ketentuan mengenai sanksi pidana diatur dalam Bab XII tentang Sanksi yaitu:

Pasal 43

(1) Barang siapa yang menghalanghalangi atau memaksa pekerja/buruh sebagaimana dimaksud dalam Pasal 28, dikenakan sanksi pidana penjara paling singkat 1 (satu) tahun dan paling lama 5 (lima) tahun dan/atau denda paling sedikit Rp. 100.000.000,00 (seratus juta rupiah) dan paling banyak Rp.500.000.000,00 (lima ratus juta rupiah).

(2) Tindak pidana sebagaimana dimaksud dalam ayat (1) merupakan tindak pidana kejahatan.

Permasalahan berikutnya adalah mengenai pembuktian bahwa tindakan pemutusan hubungan kerja, mutasi, tidak membayar atau mengurangi upah sebagaimana dimaksud Pasal 28 bertujuan untuk menghalang-halangi atau memaksa pekerja/buruh dalam berserikat. Hal ini membutuhkan keahlian penyidik dalam menilai tindakan tersebut apakah ada keterkaitan dengan aktivitas serikat pekerja/serikat buruh, mengingat sangat jarang sekali atau bahkan tidak mungkin pengusaha mencantumkan alasan dari tindakan tersebut dikarenakan pekerja/buruh yang bersangkutan menjadi anggota atau mengikuti kegiatan suatu serikat pekerja/serikat buruh.

Ketentuan pidana dalam Undang-Undang Nomor 13 Tahun 2003 tentang Ketenagakerjaan yang berkaitan dengan perlindungan hak 
kebebasan berserikat terdapat dalam ketentuan berikut:

Pasal 143

(1) Siapapun tidak dapat menghalang-halangi

pekerja/buruh dan serikat pekerja/serikat buruh untuk menggunakan hak mogok kerja yang dilakukan secara sah, tertib, dan damai.

(2) Siapapun dilarang melakukan penangkapan dan/atau penahanan terhadap pekerja/buruh dan pengurus serikat pekerja/serikat buruh yang melakukan mogok kerja secara sah, tertib, dan damai sesuai dengan peraturan perundang-undangan yang berlaku.

Pasal 144

Terhadap mogok kerja yang dilakukan sesuai dengan ketentuan sebagaimana dimaksud dalam Pasal 140, pengusaha dilarang:

a. mengganti pekerja/buruh yang mogok kerja dengan pekerja/buruh lain dari luar perusahaan; atau

b. memberikan sanksi atau tindakan balasan dalam bentuk apapun kepada pekerja/buruh dan pengurus serikat pekerja/serikat buruh selama dan sesudah melakukan mogok kerja.

\section{Pasal 185}

(1) Barang siapa melanggar ketentuan sebagaimana dimaksud dalam Pasal 42 ayat (1) dan ayat (2), Pasal 68, Pasal 69 ayat (2), Pasal 80, Pasal 82, Pasal 90 ayat (1), Pasal 143, dan Pasal 160 ayat (4) dan ayat (7), dikenakan sanksi pidana penjara paling singkat 1 (satu) tahun dan paling lama 4 (empat) tahun dan/atau denda paling sedikit Rp100.000.000,00 (seratus juta rupiah) dan paling banyak $R p \quad 400.000 .000,00$ (empat ratus juta rupiah);

(2) Tindak pidana sebagaimana dimaksud dalam ayat (1) merupakan tindak pidana kejahatan.

Pasal 187

(1) Barang siapa melanggar ketentuan sebagaimana dimaksud dalam Pasal 37 ayat (2), Pasal 44 ayat (1), Pasal 45 ayat (1), Pasal 67 ayat (1), Pasal 71 ayat (2), Pasal 76, Pasal 78 ayat (2), Pasal 79 ayat (1) dan ayat (2), Pasal 85 ayat (3), dan Pasal 144, dikenakan sanksi pidana kurungan paling singkat 1 (satu) bulan dan paling lama 12 (dua belas) bulan dan/atau denda paling sedikit Rp 10.000.000,00 (sepuluh juta rupiah) dan paling banyak $R p \quad 100.000 .000,00$ (seratus juta rupiah).

(2) Tindak pidana sebagaimana dimaksud dalam ayat (1) merupakan tindak pidana pelanggaran.

Undang-Undang Republik Indonesia Nomor 9 Tahun 1998 Tentang Kemerdekaan Menyampaikan Pendapat di Muka Umum Pasal 18

(1) Barang siapa dengan kekerasan atau ancaman kekerasan menghalang-halangi hak warga negara untuk menyampaikan pendapat di muka umum yang telah memenuhi ketentuan Undang-undang ini dipidana dengan pidana penjara paling lama 1 (satu) tahun. 
(2) Tindak pidana sebagaimana dimaksud dalam ayat (1) adalah kejahatan.

Ketentuan pidana dalam Undang-Undang Nomor 9 Tahun 1998 untuk menjamin dan memberikan perlindungan hak kebebasan tiap warga Negara untuk menyampaikan pendapat, pikiran, gagasan baik berupa lisan maupun tulisan di depan umum. Undangundang hanya melindungi pelaksanaan hak kebebasan menyampaikan pendapat yang sesuai dengan perundag-undangan yang berlaku yakni menyampaikan surat pemberitahuan secara tertulis ke kepolisian, dilakukan secara tertib, menjaga keamanan dan ketertiban umum, menghargai hak kebebasan orang lain dan sebagainya.

2. Kebijakan Aplikasi Hukum Pidana di Indonesia Dalam Melindungi Hak Kebebasan Berserikat Bagi Pekerja/Buruh yang Berlaku Saat Ini;

Perlindungan hukum atas hak kebebasan berserikat bagi pekerja/buruh tidak hanya dimaknai sebatas perlindungan hak pekerja untuk membentuk atau menjadi anggota serikat pekerja saja, akan tetapi selain menyangkut hak individu, yang lebih substansi adalah perlindungan terhadap hak serikat pekerja itu sendiri. Di satu sisi, harus diakui bahwa kebebasan pekerja untuk membentuk serikat pekerja dalam tataran kebijakan hukum dan aplikasinya sudah berjalan dengan baik, yang dibuktikan dengan mudahnya bagi pekerja untuk membentuk serikat pekerja baik ditingkat perusahaan maupun diluar perusahaan, termasuk membentuk Federasi Serikat Pekerja dan Konfederasi Serikat Pekerja.

Namun di sisi yang lain, setelah serikat pekerja itu terbentuk, pengakuan dan penghargaan atas hak serikat pekerja itu sendiri telah diabaikan. Padahal hak serikat pekerja ini yang lebih substantif baik dalam konteks perlindungan hak-hak pekerja dan peningkatan kesejahteraan, tetapi juga perjuangan politik serikat pekerja dalam mempengaruhi kebijakan publik baik yang berupa peraturan perundangundangan, penetapan upah minimum maupun kebijakan yang menyangkut ketenagakerjaan lainnya.Dalam penulisan ini juga ada studi kasus tindak pidana kebebasan berserikat yang terjadi di PT. King Jim Indonesia, Pasuruan, Jawa Timur, kasus ini merupakanyang pertama kali dan satu-satunya kasus di Indonesia yang diproses sampai ke pengadilandan berkekuatan hukum tetap.

\section{Kebijakan Formulasi Hukum Pidana di Indonesia Dalam Melindungi Hak Kebebasan Berserikat Bagi Pekerja/Buruh yang Akan Datang.}

Penelitian ini berusaha menyajikan dan memberikan masukan mengenai konsep kebijkan hukum pidana yang akan datang. Hingga saat ini, belum ada satu rancangan undang-undang yang akan mengatur lebih kompleks perlindungan hak kebebasan berserikat, konsep Kitab UndangUndang Hukum Pidana tahun 2012 juga tidak memasukkan konsep tindak pidana terhadap hak buruh atau tindak pidana di bidang ketenagakerjaan, sementara tindak pidana khusus lainnya seperti tindak pidana korupsi, tindak pidana penyalahgunaan narkotika, tindak pidana lingkungan hidup, tindak pidana pelayaran, dan lain 
sebagainya, sudah masuk dalam konsep KUHP. Selain itu, dalam tindak pidana terhadap Hak Asasi Manusia, juga tidak memasukkan tindak pidana penghalangan atau pemaksaan kebebasan berserikat, yang notabene hak berserikat merupakan bagian dari Hak Asasi Manusia. Untuk itu, dalam bagian ini akan membahas konsep KUHP tahun 2012 dan perbandingan hukum di Negara lain yaitu di Ukraina dan Republik Armenia. ${ }^{14}$

Mengingat rumusan tindak pidana penghalangan kebebasan berserikat belum ada dalam konsep KUHP 2012, maka dalam hal ini dicari yang ada kaitannya dengan tindak pidana ini, yaitu:

Pasal 576

(1) Dipidana dengan pidana penjara paling lama 2 (dua) tahun atau pidana denda paling banyak Kategori III, setiap orang yang: a. secara melawan hukum memaksa orang lain supaya melakukan, tidak melakukan, atau membiarkan sesuatu dengan memakai kekerasan, atau suatu perbuatan lain atau ancaman perbuatan lain, untuk melakukan, tidak melakukan atau membiarkan sesuatu baik terhadap orang tersebut maupun terhadap orang lain; atau; b. Memaksa orang lain supaya melakukan, tidak melakukan atau membiarkan sesuatu dengan ancaman pencemaran nama atau pencemaran nama secara tertulis.

(2) Pembuat tindak pidana sebagaimana dimaksud pada ayat (1) huruf b hanya dapat dituntut atas pengaduan orang yang terkena tindak pidana.

\footnotetext{
${ }^{14}$ Sumber data KUHP dan Undang-Undang di Republik Armenia dan Ukraina dari www.legislationline.org, diakses tanggal 12 Desember 2012
}

a) Ukraina

- Article 170. Preclusion of legal activities of labor unions, political parties, and nongovernmental organizations.

Willful preclusion of legal activities of labor unions, political parties, and non-governmental organizations or their organs, -

Shall be punishable by correctional labor for a term up to two years, or imprisonment for a term up to three years, with the deprivation of the right to occupy certain positions or engage in certain activities for a term up to three years.

Ketentuan pidana Pasal 170 bukan hanya memberikan perlindungan bagi serikat buruh saja tetapi juga partai politik dan organisasi masyarakat lainnya, artinya hak rakyat untuk berorganisasi, mengeluarkan pendapat dan berkreativitas benarbenar dilindungi. Dan yang menarik adalah ketentuan pidana penghalanghalangan kebebasan berorganisasi dicantumkan dalam KUHP, sedangkan dalam undang-undang lainnya seperti Undang-Undang tentang Organisasi Masyarakat (Civic Association Law in Ukraine) mengatur lebih detail hak, kewajiban, perlindungan dan hal-hal yang dilarang dilakukan oleh organisasi masyarakat, tetapi tidak mencantumkan ketentuan pidana di dalam undang-undang ini.

Article 174. Compulsion to participate in a strike or preclusion from participation in a strike. Compulsion to participate in a strike or preclusion from participation in a strike, by violence or threats of violence or any other unlawful actions. shall be punishable by a fine up to 50 tax-free minimum incomes, or community service for a term of 
100 to 240 hours, or arrest for a term up to six months, or restraint of liberty for a term up to three years.

Ketentuan pidana Pasal 174 diatas, menitikberatkan pada perlindungan hak buruh untuk melakukan mogok kerja yang sebenarnya merupakan hak dari serikat buruh untuk menyelenggarakan dan melaksanakan pemogokan. Rumusan ketentuan pidana diatas, perbuatan yang dilarang dan dapat diancam pidana adalah tindakan memaksa atau menghalang-halangi seseorang untuk mengikuti atau tidak mengikuti pemogokan, dengan kekerasan atau ancaman kekerasan atau dengan tindakan melanggar hukum lainnya. Artinya bahwa hak individu untuk mengikuti atau tidak mengikuti pemogokan, hak mogok dilaksanakan dengan sepenuhnya kebebasan setiap orang untuk memilih dengan tanggung jawab.

\section{b) Armenia}

Perlindungan atas hak kebebasan untuk membentuk organisasi dan menjalankan kegiatan organisasi diatur dalam Konstitusi dan KUHP Republik Armenia (Constitution and Criminal Code of the Republic of Armenia). Dalam Konstitusi Republik Armenia pasal 25 menyebutkan:

Everyone has the right to create an association, trade union, or political party, as well as to be a member thereof. Limitations are placed only on police officers and those serving in the military. No one can be forced to become a member of an association.

Kebijakan hukum pidana di Republik Armenia untuk memberikan perlindungan hak kebebasan berorganisasi, diatur dengan jelas dalam KUHP (Criminal
Code of Republik Armenia, 2003) khususnya dalam Pasal 155 dan 161, adalah sebagai berikut:

- Article 155. Forcing to refuse from participation in a strike or forcing to participate in a strike.

Forced participation in a strike or forced hindrance to the participation in a legal strike by means of violence or threat of violence, is punished with a fine in the amount of 200 to 400, or with arrest for the term of up to 2 months.

- Article 161. Hindrance to the right to establish associations (non-governmental organizations or trade unions) or parties, or hindrance to their activities.

1. Hindrance to the right to establish associations or parties, or hindrance to their legal activities or intervention, is punished with a fine in the amount of up to 100300 minimal salaries, or with arrest for the term of up to 1 month.

2. The same act which caused essential breach of the rights or legal interests of the association or party, is punished with a fine in the amount of 200-400 minimal salaries, or arrest for up to 2 months.

\section{Simpulan}

Berdasarkan pada perumusan masalah dan uraian hasil penelitian dan pembahasan pada bab sebelumnya, dapat ditarik suatu kesimpulan sebagai berikut:

1. Kebijakan hukum pidana dalam perlindungan hak kebebasan berserikat bagi pekerja/buruh Indonesia dalam kaitan dengan Hak Asasi Manusia saat ini adalah dengan menggunakan Kitab Undang-Undang Hukum Pidana (KUHP), Undang- 
Undang Nomor 21 Tahun 2000 tentang Serikat Pekerja/serikat Buruh, Undang-Undang Nomor 13 Tahun 2003 tentang Ketenagakerjaan, UndangUndang Nomor 9 Tahun 1998 tentang Kemerdekaan Menyampaikan Pendapat di Muka Umum. Dalam kenyataannya masih terdapat beberapa kelemahan, baik dalam perumusan tindak pidana seperti perumusan deliknya yang masih bersifat umum dan tidak memberikan pengertian serta batasan-batasan dari rumusan delik pidananya. Perumusan pertanggungjawaban pidananya yang tidak jelas, tidak terperinci dan tidak adanya rumusan pertanggungjawaban korporasi dalam tindak pidana kebebasan berserikat. Sistem perumusan sanksi pidana yang kurang tepat dan tidak adanya aturan atau pedoman pemidanaannya.

2. Kebijakan aplikasi hukum pidana saat ini dalam perlindungan hak kebebasan berserikat bagi pekerja/buruh Indonesia dalam kaitan dengan Hak Asasi Manusia untuk penyidikan dalam penegakan hukum selain kepolisian juga diberikan wewenang kepada Pejabat Pegawai Negeri Sipil (PPNS) yang bertugas pada instansi yang bertanggungjawab di bidang ketenagakerjaan. Dalam pelaksanaannya Pejabat Pegawai Negeri Sipil (PPNS) yang diberikan kewenangan oleh Undang-undang untuk melakukan penyidikan dan secara materi lebih menguasai masalah ketenagakerjaan akan tetapi tidak dapat melaksanakan tugasnya dengan baik, hal ini terbukti dengan tidak adanya pelaku tindak pidana kebebasan berserikat yang diproses hukum sampai pengadilan, padahal kasus-kasus penghalangan atau pemaksaan kebebasan berserikat banyak terjadi di perusahaan/tempat kerja.

3. Kebijakan formulasi hukum pidana dalam perlindungan hak kebebasan berserikat bagi pekerja/buruh Indonesia dalam kaitan dengan Hak Asasi Manusia yang akan datang, hanya terdapat pada konsep KUHP 2012 yaitu mengenai Tindak Pidana terhadap Kemerdekaan Orang, tidak secara khusus mengenai tindak pidana kebebasan berserikat.

\section{Saran}

Berdasarkan pada hasil penelitian yang telah dikemukakan diatas, maka penulis memberikan beberapa saran sebagai berikut:

1. Perumusan tindak pidana dibidang ketenagakerjaan atau khususnya tindak pidana kebebasan berserikat diatur dalam Kitab Undang-Undang Hukum Pidana (KUHP) seperti halnya tindak pidana khusus lainnya yang sudah masuk dalam konsep KUHP. Dalam konteks pembaharuan hukum pidana, pengaturan tindak pidana kebebasan berserikat di dalam KUHP menjadi penting dalam memberikan perlindungan atas hak kebebasan berserikat setiap orang khususnya para pekerja/buruh.

2. Pemerintah melakukan evaluasi, pembinaan dan perbaikan kinerja pegawai pengawas ketenagakerjaan dan pejabat Penyidik Pegawai Negeri Sipil 
yang bertugas pada instansi yang bertanggungjawab dibidang ketenagakerjaan. Perlu adanya evaluasi kerja, pembinaan dan peningkatan sumber daya manusia pegawai pengawas dan PPNS untuk meningkatkan kemampuan dan menunjang efektivitas kerja dalam melakukan pengawasan dan penyidikan pelanggaran ketentuan hukum ketenagakerjaan.

3. Pemerintah mengeluarkan kebijakan kepegawaian agar seluruh pegawai pengawas dan pejabat PPNS ditarik kembali status kepegawaiannya pada Kementerian (Pemerintah Pusat). Hal ini untuk menghindari intervensi dan kepentingan politik dari pejabat di daerah serta kesatuan kerja dan program pengawasan ketenagakerjaan secara nasional dan sinergitas yang baik.

\section{Daftar Pustaka}

Barda Nawawi Arief, Bunga Rampai Kebijakan Hukum Pidana, Gramedia Pustaka Utama, 2002

Direktur Pembangunan Hubungan Industrial, Kementerian Tenaga Kerja dan Transmigrasi Republik Indonesia, tanggal 15 Mei 2008

http://hukumonline.com/, diakses 5 Juli 2012

http://siaranpers.blogspot.com/, diakses 5 Juli 2012

http://www.hukumonline.com/, diakses 5 Juli 2012 http://www.suaramerdeka.com/, diakses 5 Juli 2012

Kamus Besar Bahasa Indonesia, Jakarta, Balai Pustaka, 1990

Loren Bagus, Kamus Filsafat, Jakarta: Gramedia Pustaka Utama, 2002

Soerjono Soekanto \& Sri Mamudji, Penelitian Hukum Normatif, Suatu Tinjauan Singkat, Rajawali, Jakarta, 1985

Sumber data KUHP dan UndangUndang di Republik Armenia dan Ukraina dari www.legislationline.org, diakses tanggal 12 Desember 2012

Trade Union Right Centre, "Kebebasan Berserikat Jalan di Tempat", Jakarta: 1 September 2008

wawancara dengan Soeharjono (National Project Coordinator ILO / ACTRAV Jakarta), di Jakarta, 15 Februari 2009 